\title{
L.N. Tolstoy, A. Škarvan and D.P. Makovický in the Context of Russian-Slovak Relations
}

\author{
Natalia A. Bondarenko \\ Department of Regional and International Relations \\ L.N. Tolstoy Institute for Languages and Cultures \\ Moscow, Russia \\ E-mail: b_natalia@mail.ru
}

\begin{abstract}
The article reveals the activities of the Slovak followers of Tolstoy such as A. Škarvan and D.P. Makovický. A. Škarvan and D.P. Makovický communicated with L.N. Tolstoy, accepted his religious-philosophical ideas and tried to put them into practice in the Slovak lands. D.P. Makovický spoke about his memories of Tolstoy, life in Yasnaya Polyna in "Yasnaya Polyana Notes" (1904 - 1910). A. Škarvan shared his thoughts in "Notes of a Military Doctor." The relationship between L.N. Tolstoy and the Slovak figures are one of the pages in the history of Russian-Slovak relations.
\end{abstract}

Keywords-L.N. Tolstoy; A. Škarvan; D.P. Makovický; "Tolstoyism"; religious and philosophical ideas; Russian-Slovak relations

\section{INTRODUCTION}

The relationship between the two Slavic peoples, historical and cultural ties, philosophical and literary bonding of Russia and Slovakia are described in detail in the studies undertaken by many scientists: V. Matula, Member of Slovak Academy of Sciences, the Professor D. Kodayová, T. Ivantishinova and others, as well as Russian scientists and professors such as M. Yu. Dostal, G.P. Melnikova, G.V. Rokina and etc. [1] However, at present, the tendencies for the critical re-examination of problems associated with the Slavic ideology and Slovak-Russian ties are being observed in the Slovak historiography. The purpose of such phenomenon is obvious: to weaken Russia's positions, to make it isolated from the Central European region.

It should be reminded that the first programmes for inclusion of the Slovaks in the political agenda came from the Decembrists. In the '30s-'40s of the 19th century, Russian scholars, when making visits to the Slovak lands, noticed a special amiable disposition expressed by the Slovaks towards the Russians. In 1866, the Slavic Teachers' Institute opened in Petersburg (where the teachers of the Kingdom of Poland were initially trained). Among the scholarship holders there were also the Slovak students.

In 1867 , on the eve of the Slavic congress, the Slovak Ludovít Stúr's treatise called "Slavdom and the world of the future" (in Russian) saw the light in Moscow. This work came as a clear confirmation of Russian-Slavic ties.

\section{ThE FIRST TRANSLATIONS OF L.N. TOLSTOY’S WORKS INTO SLOVAK}

In this regard, of interest is L.N. Tolstoy's philosophical heritage, as well as the efforts of the Slovaks A. Škarvan and D.P. Makovický towards the popularization of the Russian writer's works in the Slovak lands. These aspects are explained more fully in I.M. Porochkina's monograph called "L.N. Tolstoy and the Slavic peoples." [2]

The Slovak general public's encounter with L.N. Tolstoy's works began with the translation of a story called "The Raid" (Nabeg) published in Orel Magazine (1876). From the '80s of the 19th century the works of the Russian writer started to appear on the pages of many magazines.

One of the first "to uncover" L.N. Tolstoy for the Slovaks was Svetozár Hurban-Vajanský (1847-1916). He visited Russia several times, wrote an article entitled "Earl L.N. Tolstoy as an artist and a wise man" that was printed in the Russian journal "Slavic Review" (Slavyanskoye Obozrenie), in which he shared his impressions of what he saw. He recalled a meeting with the Slavist V.I. Lamansky, who drew the attention of S. Hurban-Vajanský "to such topstone as Tolstoy! "Great artist!" he said to me. But I was incredulous! Can anyone be great after Turgenev, after I. Goncharov (I had just made acquaintance with the novel "Oblomov" at that time), next to F.M. Dostoyevsky (I had just read "Crime and Punishment" at that time) and, moreover, at our not-so-abundant times!" [3] Later, in his letter of March 23, 1884 to the Slavist T.D. Florinsky, the Slovak writer will write: "Of Tolstoy, I have read "War and Peace" and "Anna Karenina." A great artist! [4]

In 1899, L.N. Tolstoy's novel "Resurrection" (translated by Albert Škarvan), which has been published by the doctor D.P. Makovický (1866-1921), makes appearance in the Slovak lands. Then, he translates the Russian writer's ethical-religious works, which, unfortunately, are not met with a response of the Slovaks. Nonetheless, L.N. Tolstoy's folk tales, that D.P. Makovický had published using his own funds, became very popular (19 books came out over the period from 1896 to 1989). [5]

For the Slovak realism that "had been forming half a century behind, as compared to other European literatures," 
According to D.P. Makovický, Lev Nikolayevich cannot [6] it was this part of the Tolstoy's heritage that became the most renowned.

\section{D.P. MAKOVICKÝ AND HIS "YASNAYA POLYANA NOTES”}

Dušan Petrovič Makovický (1866-1921) graduated from Prague University, undertook internship in Innsbruck and Moscow, worked as a doctor in the Slovak town Žilina, while ever-willingly helping poor families. In 1894, he came to Yasnaya Polyana, made acquaintance with L.N. Tolstoy. He resided in Yasnaya Polyana since 1904, became a loyal follower of L.N. Tolstoy's teaching and the writer's personal physician, and stayed with him until his death. Life in its entirety and diversity unfolds before us on the pages of four volumes of "Yasnaya Polyana Notes" by D.P. Makovický." [7]

From the first lines we get involved into the writer's intensive work: not a day goes by without working on the writings, without responses to the letters, talks on the sensible subjects - before us there unfurls a broad panorama of the great writer's life.

The general tone of the Notes is reserved one - and this is understandable: Dušan Petrovič was consciously suppressing in himself a litterateur, a memoirist, while avoiding value judgments, because he was creating a chronicle document about Tolstoy.

The time of the turn of the century (the end of the $19^{\text {th }}$ century - the beginning of the $20^{\text {th }}$ century) is the time of tragic events in Russian history: the loss of the Russian battleships during the Port Arthur raid, the revolutionary events of 1905-1907, the purges, the Stolypin Reform. It's at that time that "the Tolstoyism"1 gains weight in the sociopolitical life of the country. During the reactionary "dark years" a part of the Russian society is carried away by the ideas coming from the Russian writer concerning the improvement of the social life through self-improvement of each person, about "non-resistance to evil by force," about the necessity of living by one's own labour.

In "Yasnaya Polyana Notes" D.P. Makovický makes a record of L.N. Tolstoy's reaction to the developments taking place during the Revolution of 1905-1907: the objections raised by the writer to the revolutionary solution to the crisis - in the spirit of his teaching on non-resistance to evil by force - are combined with thoughts about the historical meaning of the events: "Our civilization - one of the many is nearing its end. A new path must be taken." [8] Sensing tragic events for Russia, L.N. Tolstoy stresses that "...the revolution in Russia will begin, but... by means of spreading intellectual and economical upbringing and, especially, through the fact that people will produce revolution in their own personal life." [9]

Tolstoyism is a religious-ethical social current in Russia of the end of the 19th -the beginning of the 20th century. It emerged in $1880 \mathrm{~s}$ under the influence of the religious-philosophical teaching given by Leo Tolstoy. The principles of the Tolstoysim are described by Tolstoy in his works "Confession," "What I Believe," "On Life," "The Christian teaching" and others. be blamed for misunderstanding the spirit of the age. In the waning years of "the unruly decade" (F.M. Dostoyevsky), he was able to determine the direction of one of the paths, which people could take i.e. moral self-improvement of a person himself: "...no changes in external forms of human life can make us reach the well-being that can be reached through the work of each separate individual in the area of his self-improvement." [10] This path that was chosen by Tolstoy in the pivotal era, at the core of which had been moral-and-ethical strivings, as well as religious choice, was not an exception for the thinking public not only in Russia, but also in Slovakia.

Of interest in this respect are the statements expressed by the writer concerning the paintings of M.V. Nesterov. In comments on the portrayal of Christ, we hear different positions of the two great artists on the subject of Orthodox Christianity.

Mikhail Vasilyevich was a frequent visitor to Yasnaya Polyana, he expressed his perception of Tolstoy in a letter to A.A. Turylin: "Tolstoy is an elder, he is a poem... The fact that he is an artist is his justification for his great lightmindedness, for his "mischievous" philosophy and moral. ...Wily lord who is always carried away by something and who charms others with the flexibility of his great talent... He is like a deity who, unaware of his power, entices the weak ones, leaves them wallowing in their broken distorted ideals. He is a great artist and a great mischief." [11]

"The Nesterov theme" can often be heard in conversations taking place in Yasnaya Polyana in the '900s. In June 1907, Makovický points out: "Nesterov and I were talking about Lev Nikolayevich's opinion on his (Nesterov's) painting "The Appearance of Christ before the People."[Note: here the author probably refers to the painting "Holy Russia."] I said that Christ was portrayed differently to what the Russian devotees, who stand before him, picture to themselves and see, he was more like a stately proud Italian man, and that this painting was "the last rites of Orthodox Christianity" (L.N. Tolstoy). [12] M.V. Nesterov agreed that he didn't manage to put Christ on canvas and that he came out as overbearing, triumphant, but disagreed on Tolstoy's opinion that "a funeral service" had already been read over Orthodox Christianity. In the painter's opinion, Orthodox Christianity was composed of searching for the truth by thousands of people. "The people who has given the world Pushkin, Dostoyevsky and Tolstoy is undying, Orthodox Christianity is more powerful than my painting, it is the people's poetry." [13]

These painter's words tell us about the continuation of arguments with L.N. Tolstoy that have arisen as far back as in the time of the first-time meeting, and about Nesterov's non-acceptance of "the Tolstoyan rationalism." Given the profound respect for the writer, the artist was that irreconcilable in relation to the L.N. Tolstoy's "path."

In Makovický's "Yasnaya Polyana Notes" we see Tolstoy not only as a famous public figure and a philosopher, but we add many interesting details to the writer's image: the movement of his thoughts, feelings and inner turmoil. For 
strong-willed non-obedience and about moral opposition of the church to secular authorities. "What a wonderful personality! At the end of the $16^{\text {th }}$ century, he denied the church and the state, it's what we come to these days, and he remained unknown to the whole world due to his modesty." [22] The excerpts from P. Chelčický's "The Net of True Faith" were included by the writer in his collected works "A Cycle of Readings."

It should be noted that the Czechs, who were familiar with literary works and philosophical treatises of the Russian writer, called him "a modern-day Chelčický." It was reported by Jaroslav Janáček, a Czech admirer of the Russian writer: “...aź lid naš český ... přijme ho za svého moderniho...” Chelčický (translation: "...our Czech people... will accept him as their modern Chelčický”). [23] A. Skarvan's act was seen as following the L.N. Tolstoy's principle of nonresistance to evil by force.

If at the beginning of his spiritual way A. Škarvan accepted the writer's many views, he saw the principal merit in the fact that it was he (L.N. Tolstoy) who "helped me, lost and errant one, find myself" [19] by indicating the true path to the Almighty.

At the beginning of the $20 \mathrm{~s}$ of the $20^{\text {th }}$ century, A. Škarvan reconsidered many things. At the end of life, the Slovak physician, just like, in particular, M. Nesterov, denied "the Tolstoyan rationalism." He emphasized that the main way of a human being is his desire to live, while respecting Christian dispensations.

In his diary as of October 30, 1925, A. Škarvan wrote that "mercy, forgiveness and generosity are the most reliable touchstones of a person's spiritual values. Without these qualities it's impossible to be a Christian and impossible to be a kind person. Without love of God, there's neither truth, nor happiness. It's in vain that people try to bypass God and be saved without God." [23]

It appears from his last diary records that, in terms of his Christian views, A. Škarvan went ahead of his "spiritual teacher," became closer to F.M. Dostoyevsky who had understood what life without Christ was.

Already at the end of life, in 1926, A. Škarvan noted that "the road of life comes up to God. It's not a philosophical formula, but the life experience of all intelligent, honest people. We should reach the path. People are on the wrong track. And even worse, while being of the wrong track, people believe that they follow the right way, so, the world is far off the mark, it mires in lies, and this is its big and only problem" (as of March 7, 1926). [23]

With regret A. Škarvan said that those who had considered themselves Tolstoyists and his followers did not understand L.N. Tolstoy. And that was also a tragedy for the writer who missed a profoundly religious person by his side.

\section{CONCLUSION}

The memoir-literature works "Yasnaya Polyana Notes" (by D.P. Makovický) and "Notes of a Military Doctor" (by A. Śkarvan) crack open new pages of the many-sided life of the 
[20] Šalda F. X. In memoriam Alberta Skarvana. - Rozpravy Aventina, 1926

[21] Bogatyrev P.G. As seen by a Slovak friend. - From the book: Literary Heritage, Vol. 75, Book 2, pp. 121-132

[22] Korina N.B. The interpretation of Tolstoyan philosophy in the diaries of the Slovak Tolstoyist A. Škarvan // Gumanitarnye Vedomosti ("Humanitarian Journal") Tula State Lev Tolstoy Pedagogical University. No. 3 (27), Vol. 1. 2018, pp. 135-149.

[23] Šalda F. X. In memoriam Alberta Skarvana. - Rozpravy Aventina, 1926, p. 8.

\section{REFERENCES}

[1] Czechia and Slovakia in the 20th century: historical essays. M.: Nauka Publishing House, Books 1, 2, 2005. (20th century in documents and researches)

[2] Theory and practice of the Slavic reciprocity in the history of SlovakRussian relations, the 19th century - Kazan: the publishing house of Kazan State University, 2005

[3] Konec druhej svetovej vojny a problémy cirkevnej politiky $\mathrm{v}$ nasledujúcom období ("The end of World War II and problems of ecclesiastical policy in the following period" / Composed by M. Barnovský, D. Kodajová. Bratislava, 2006

[4] The Russians and the Slovaks in the 19th and the 20th centuries: contacts, interactions, stereotypes/ Responsible editor V.A. Tishkov. M.: Yoshkar-Ola, 2007

[5] M. Danish. From the history of Slovak-Russian relations in the 18th century //Zapad-Vostok ("West-East"). 2017. No. 10. Pages 20-47

[6] M. Danish, V. Matula. M.F. Rajevskij a Slovaci v 19. Storoci ("M.F. Rajevskij and the Slovaks in the 19th century"). Bratislava, 2014.

[7] Porochkina I.M. L.N. Tolstoy and the Slavic peoples: literary-andaesthetical and socio-philosophical interrelations of the second half of the 19th century - the beginning of the 20th century. L., LGU Publishing House, 1983.

[8] Petrus P. Svetozár Hurban-Vajanský's trips to Russia. - From the book: Czech-Russian and Slovak-Russian literary relations at the end of the 19th - the beginning of the 20th century. M., 1968, p. 209.

[9] Korešpondencia Svetozára Hurbana-Vajanského ("Svetozár HurbanVajanský. Correspondence"), Bratislava. 1967, p. 261.

[10] Lesnáková S. Ludovýchovné poviedky L. N. Tolstého a jeho slovenských súčasníkov ("Folk stories by L. N. Tolstoy and his Slovak contemporaries") // Slavica Slovaca magazine, No. 14, 1979, p. 2.

[11] Lesnáková S. Lev Nikolajevic Tołstoj a Slovenská realistická literature ("Lev Nikolayevich Tolstoy and the Slovak realistic literature"). - In: Československé přednášky pro VIII. mezinárodního sjezdu slavistů v Záhřebu ("Czechoslovak lectures for the 8th International Congress of Slavists in Zagreb"). Praha, 1978, p. 145.

[12] Literary Heritage. Vol. 90 in 4 books. At Tolstoy's. 1904-1910; Yasnaya Polyana Notes by D.P. Makovický. - M, Nauka Publishing House, 1979 (followed by the references to this edition: Book 1, 1904-1905. - M., Nauka Publishing House, 1979).

[13] Literary Heritage. Vol. 90 in 4 books. At Tolstoy's. 1904-1910; Yasnaya Polyana Notes by D.P. Makovický. - M, Nauka Publishing House, 1979: Book 1, 1905-1905. - M., Nauka Publishing House, p. 331.

[14] Literary Heritage. Vol. 90 in 4 books. At Tolstoy's. 1904-1910; Yasnaya Polyana Notes by D.P. Makovický. - M, Nauka Publishing House, 1979: Book 1, 1905-1905. - M., Nauka Publishing House, 1979, p. 189

[15] Literary Heritage. Vol. 90 in 4 books. At Tolstoy's. 1904-1910; Yasnaya Polyana Notes by D.P. Makovický. - M, Nauka Publishing House, 1979: Book 1, (1905-1905) M., Nauka Publishing House, 1979, p. 109

[16] Nesterov M.V. Correspondence. Selected letters. - L., 1988. - PP. 220-221

[17] Book 3 (1908-1909). -M., 1979. - P. 581.

[18] Book 2 (1906-1907). - M., Nauka Publishing House, 1979. - PP. 465-466.

[19] Book 1 (1904-1905). - M., Nauka Publishing House, 1979. - P. 108.
[24] Yasnaya Polyana Notes (1904-1910), 2nd edition. - M., 1923, p. 83.

[25] Štěpán J. Kolafa. K souhvězdí ruské literatury ("To the constellation of Russian literature") (D.Makovický u L.N. Tolstého). Praha, 1982.

[26] Quoted after Korina N.B. The interpretation of the Tolstoyan philosophy in the diaries of the Slovak Tolstoyist A. Škarvan // Gumanitarnye Vedomosti ("Humanitarian Journal") Tula State Lev Tolstoy Pedagogical University. No. 3(27), Vol. 1. 2018, p. 142. 